\title{
Neoliberalization, De-democratization, and Populist Responses in Western Europe, the US, and Latin America
}

Critical Sociology

2020, Vol. 46(7-8) II73-1 I87

(C) The Author(s) 2020

Article reuse guidelines: sagepub.com/journals-permissions DOI: I0.1 I77/0896920520927456 journals.sagepub.com/home/crs

\section{John Brown}

Maynooth University, Ireland

\begin{abstract}
This article argues that multipronged de-democratization processes over the course of neoliberal projects fostered unstable democratic equilibria in Western and Latin American democracies, opening space for populist leaders and parties to emerge. To comprehend the variation in the nature of populists that gained support, the form of neoliberalization process in each region and the consequent impacts on traditional party systems is accounted for. Moreover, the impact of region-specific factors on populist forms such as economic crises, immigration levels, and the existence of progressive social movements are accounted for. The conflux of neoliberal dedemocratization, austerity, and immigration fostered a conservative nativist-populism in Western cases. In Latin America, neoliberal de-democratization and austerity, in the presence of powerful popular movements, witnessed the emergence of a more progressive populism.
\end{abstract}

\section{Keywords}

democratization, neoliberalism, populism, Latin America, nativism

\section{Introduction}

Writers from a diversity of traditions examining European, US, and Latin American contexts have described a populist turn in recent times. Much of the analysis lumps together figures such as Hugo Chávez and Donald Trump, detailing how their discursive styles and lack of respect for liberal norms threaten democracy. However, such comparisons often obfuscate more than they enlighten. Three issues require clarification. First, rather than simply evaluating the impact of populism on liberal democracy, it is necessary to grasp its root causes. Second, a more nuanced conceptualization of the varying forms of populism is required. Third, we need to grasp why populisms vary by context. Responding to these issues, the argument presented here locates populisms as responses to variegated neoliberalization processes, which fostered de-democratization processes. That is, 
while each context varies, neoliberalization processes in Western and Latin American democracies tended to simultaneously erode the quality of political and socioeconomic citizenship for popular sectors, especially where center-left parties were involved in implementing neoliberal policies. Where socioeconomic precarity and inequality increase, while popular capacity to set the agenda or influence decision-making processes declines, democracies become unstable as popular participation and trust in political institutions and mainstream political parties erode. In such scenarios, space for populist challengers to mainstream parties/leaders widens. Populisms, then, should be understood as responses to crises of too little democracy.

While variegated de-democratization processes influence the form of populist responses, the argument outlined below suggests that specific conjunctural trigger factors also shape populist turns. That is, while democracies became unstable in the West $^{1}$ and in Latin America, variations in immigration levels, economic crises, and the presence of powerful, progressive popular social movements influenced the nature of populist response. Furthermore, by locating populisms as responses to crises of democracy as well as varied trigger factors, such responses are then conceptualized along four component-continuums. These continuums account for how popular demands for increased political and socioeconomic inclusion are incorporated, who is to be included in the populist project, as well as the nature of relations with other nations and supranational bodies. Conceptualizing populisms in this manner allow for more nuanced accounts that eschew dichotomous left/right distinctions. Moreover, rather than uncritically holding liberal democracy as the standard to aspire to, the approach taken here accounts for popular critiques of the model of democracy, thereby offering a more realistic appraisal of the causes of the "populist moment." This is not to dismiss concerns regarding the erosion of democratic norms and the dangers some populists pose. Rather, the argument here is that if we only focus on the behavior of populists in power, we risk evaluating the symptoms rather than the causes of democratic malaise. Furthermore, accounting for the role of social movements in shaping populisms overcomes biases in mainstream analyses, which assume that populism entails a top-down, autocratic leader-people relationship. Indeed, the influence of social movements on populist forms has largely been absent from analyses. The article advances as follows. First Roberts' (1998) deepening and extending framework for exploring democratization is outlined before appraising how the neoliberal era fostered de-democratization processes. Next, unstable democratic equilibria and trigger conjunctural factors are discussed. Following the establishment of the framework, populists are conceptualized in detail. Western and Latin American experiences are then analyzed and compared.

\section{Democratization Beyond Polyarchy}

Democratization involves two components; a deepening and an extending (Roberts, 1998). The logic of deepening democracy involves "intensifying popular sovereignty in the political sphere, that is, moving from hierarchical forms of elitist or bureaucratic control to forms of popular selfdetermination by means of more direct participation in the decision-making process or more effective mechanisms for holding elected representatives and public officials accountable to their constituents" (Roberts, 1998: 30). Extending democracy meanwhile "refers to efforts to extend the democratic norms and procedures of collective self-determination from the formal sphere of state institutions to new spheres of social and economic relationships" (Roberts, 1998: 30). Extending democracy is important because "social and economic inequality can easily be translated into concentrations of power in the political sphere that skew the articulation of popular interests and block the exercise of popular sovereignty" (Roberts, 1998: 29). If democratization entails a deepening and extending of democracy, de-democratization involves its opposite-a "shallowing" of political 
citizenship and popular control over decision-making processes alongside a "narrowing" of the democratic agenda to exclude issues of socioeconomic participation and inequality.

\section{Neoliberalization Processes}

While neoliberalism is a contested concept, fundamentally it is an ideology "founded on an idealized vision of market rule and liberal freedoms, combining a utilitarian conception of market rationality and competitive individualism with deep antipathies to social redistribution and solidarity" (Peck et al., 2018: 6). As Peck et al. (2018) stress, neoliberalism cannot exist in a "pure" form. Projects of neoliberalization are not simply about a withdrawal of the state, but are instead concerned with its capture and reuse. Neoliberalization processes entail both rollback politics of deregulation and dismantlement, and rollout politics of pro-corporate and market-conforming governance. The form and direction of the rollout phase is shaped by the limitations, contradictions, and failures of the experiments in the rollback phase relating to selective state withdrawal, deregulation, and privatization (Peck and Theodore, 2019: 258), which in turn is influenced by a given institutional context. While neoliberalization processes vary, this does not suggest that we cannot identify a more general trend in terms of the impacts of neoliberalization on democratic quality across regions, a task that the following section engages with. However, case-specific characteristics must be accounted for when seeking to grasp variations in neoliberalization processes, and their impacts on democratic quality, across distinct geographical terrains - a task the case study sections analyzing Western and Latin American processes engages in below.

\section{Neoliberalization and De-democratization: Shallowing and Narrowing Democracy}

Gill (1998: 23) outlines the politico-constitutional mechanisms associated with neoliberal restructuring of the global political economy, highlighting how a new constitutionalism has allowed dominant economic forces to be increasingly insulated from democratic rule and popular accountability. Rollback and rollout neoliberalization processes have "sought to create a political economy and social order where public policy is premised upon the dominance of the investor" (Gill, 1998: 23). In a globalized setting, the neoliberal drive toward a single unified field for global capitalism has significantly boosted the structural power of transnational capitalists, thereby narrowing the autonomy of domestic state managers who face pressures to promote an environment friendly to economic elite interests (Robinson, 2012: 353-358), not to labor or citizens more generally. The "mobile investor becomes the sovereign political subject" (Gill, 1998: 2). Gill (1998) defines this system of global economic governance as "disciplinary neoliberalism." Decision-making power also shifted from the nation state to international governmental organizations. Neoliberalization required increasing transnational governance due to the global integration of production and finance. That is, international policy harmony was required (Ayers and Saad-Filho, 2015: 605). As Brenner et al. (2014: 137) summarize, under market-disciplinary re-design of supranational institutional arrangements such as the OECD, World Bank, IMF, WTO, post-Maastricht EU, and NAFTA, "neo-liberalization came to restructure the very geo-institutional frameworks governing national and subnational regulatory experimentation." As such, democracy in the neoliberal era became a technocratic affair with experts in non-majoritarian institutions, including independent central banks, playing an increasingly dominant role (Mair, 2013). The rules of the game were designed to "'lock in' commitments to neo-liberalism and to 'lock out' other potential political economy alternatives" (Gill, 2008: 79). Center-left parties across much of the world accepted neoliberal reforms such as privatization of public assets, cuts to taxes and welfare spending, and 
deregulation of business and financial sectors. The traditional ideological gap between supposed left- and right-wing parties narrowed as neoliberal globalization became the only game in town. In sum then, while neoliberalization processes vary by case and region, democracy increasingly took a shallow form whereby the interests of capital were organized in and protected from democratic input, while the interests of labor and popular sectors were organized out.

As democracy becomes shallower, it also becomes narrower. That is, concerns of socioeconomic citizenship and inequality are reduced to afterthoughts to the overarching drive to provide "good" investment environments. A neoliberal rationale came to dominate conceptions of democracy and citizenship. Labor became "flexible," meaning precarious. Austerity and social-welfare retrenchment became the norm. Individual risk was increased as socialization of risk was decreased, while neoliberal policy design allowed inequality to reach unprecedented levels (Piketty, 2015). Rising economic inequality is translated back onto rising political inequality in a vicious feedback cycle, as the owners of wealth increasingly set the rules of the game that promote their own interests (Bartels, 2018; Blofield, 2011).

\section{Unstable Democracy and Conjunctural Trigger Factors}

While Brenner et al. (2014) cogently explicate the realities of variegated neoliberalization processes, the general trend of a (self-reinforcing) narrowing and shallowing of democracy, and the congealment of parties and political leaders around marketized citizenship models, fostered the development of unstable democratic equilibria in a variety of contexts. That is, liberal democracy underpinned by market rationale came under increasing pressure from swathes of society. This is not to suggest that unstable democratic equilibria necessarily lead to challenges to neoliberalization processes, which have always been adaptive and flexible, thriving in crises conditions. Rather, it is the much less adaptive traditional party systems of liberal democracies that feel the strain.

Inequalities in health, education, and economic well-being are mutually reinforcing and they condition people's overall life chances. Economic inequality "powerfully depresses political interest, discussion of politics, and participation in elections," because where "income and wealth are more concentrated, power will also be more concentrated and the less affluent will therefore be more likely to find that issues debated are not those that interest them" (Solt, 2008: 48). When "people's life opportunities are systematically undermined because of factors beyond their control, they are likely to feel disillusionment and resentment" (Solt, 2008: 48). At the same time, a consensus of the center whereby political parties fail to offer any redress to genuine popular grievances means that citizens vote in smaller numbers and with less partisan consistency, while party membership levels decline. As Schattshneider (1960) stressed, those who decide what the game is about also decide who will get into the game.

Where the interests of the wealthiest sectors of society are organized into politics, while issues concerning popular classes are increasingly organized out, democracy becomes unstable. Where party-voter distances widen, while party-party differences narrow, popular indifference and distrust of parties and political institutions more generally grows (Mair, 2013). As Schmitter (2019: 152) notes, this combination of mistrust in the political system alongside anomie and withdrawal from participation opens space for a movement of opposition that could threaten "democracy as we know it." As parties and politicians become more detached from their traditional social bases, while inequality and socioeconomic precarity become entrenched, democracy is viewed by excluded sectors as a façade for the maintenance of elite privilege, and space for populists widens. Appealing to a sense of personal danger and a shared sense of political exclusion, outsider candidates may, not wholly inaccurately, portray the political class as having failed, and that it will go on failing, effectively barring citizens from any realistic prospect of a better life (Dunn, 2019: 56). 
The argument here is that the nature and outcomes (type of populist response) of such processes vary due to context, in terms of longer-term neoliberalization processes and the subsequent forms of narrowing and shallowing, but also in terms of geographically distinct sets of conjunctural trigger factors such as the prevalence of mass immigration, economic crises/debt crises/austerity, and powerful progressive social movements. The following section develops a conceptualization for analyzing forms of populist backlash before Western and Latin American cases are analyzed.

\section{Conceptualizing Populist Responses to Unstable Democracies}

Four component-continuums to evaluate populists, both in terms of policy (and/or proposed policy) and rhetoric are outlined below. These include (A) deep/shallow participation; (B) extended/narrow citizenship;(C) progressive-pluralism/anti-migrantnativism; and(D)progressiveinternationalism/regressive-reactionary nationalism. On continuum A, the deepening pole is associated with, though not limited to, a re-politicization of politics more broadly by restricting technocratic control over issues regarding economic, health, and welfare policies; boosting spaces for popular deliberative participation; re-call referenda; and strengthening unions. The shallow pole of the continuum is associated with unaccountable, technocratic decision-making procedures dominated by capital and supranational bodies, as well as the convergence of mainstream parties around a neoliberal rationale. On continuum B, the extending pole tends toward state guarantees of social citizenship to all citizens irrespective of capacity to pay in areas including education, food, health, housing, and information. Progressive taxation, high corporation taxes, universal pensions, wealth and inheritance taxes, judicial support for workplace democracy, communal land ownership schemes, and nationalization of key sectors of the economy are some components of an extended democracy. The narrow pole of the continuum is associated with commodification of citizenship, austerity, labor flexibilization, and unfettered inequality.

On continuum $\mathrm{C}$ at the progressive-pluralism pole, all people residing in a given state are to be incorporated into the deepening and extending project. The opposite pole seeks exclusion of "outsiders," notably immigrants and ethnic minorities. On continuum D, re-politicization of national decision-making processes is key. However, at the regressive-reactionary pole, such a process is tied up with ethnic, exclusivist lines as well as anti-Islamic sentiment and anti-socialist solidarity with other nations. Progressive-internationalism, conversely, centers on a "progressive, emancipatory vision" of re-claiming control over national decision-making (Mitchell and Fazi, 2017: 12), while supporting similar processes and progressive leaders outside national boundaries.

\section{Neoliberalization and the Shallowing and Narrowing of Western Democracies}

Following the neoliberal turn of the 1970s-80s and the move away from post-WWII Keynesianism and social democracy, Western democracies became shallower and narrower. Socioeconomically, social democratic parties across Western Europe and the US moved to the right by embracing the market, albeit to differing levels in different cases. Blair's "New Labour" in the UK, Clinton's "New Democrats" in the US, and Schröder's SPD in Germany largely "accepted neoliberal policies and the idea that government's ability to shape economic and social development was limited" (Berman and Snegovaya, 2019: 9). As Berman and Snegovaya (2019: 9) emphasize, "in a dramatic reversal of the postwar pattern in which a social democratic consensus came to dominate the mainstream left and right, by the late twentieth century a neoliberal consensus dominated both instead." Economics was separated from politics, limiting the scope for democratic accountability. Popularsector concerns were squeezed out of the democratic arena, while fears of capital flight meant that 
elected state-managers increasingly responded to the demands of business. Technocratic decisionmaking in far-off supranational bodies such as the European Commission and European Central Bank reinforced sentiments amongst citizens that they were losing control over decision-making (Lapavitsas, 2019). The neoliberal turn fostered tax and regulatory competition amongst states to attract highly mobile global capital leading to the erosion of progressive tax systems and other key social welfare institutions required to tackle inequality. Economic inequality, which had declined in advanced industrial societies for much of the 20th century due to progressive tax systems, rose steeply from the 1970s (Piketty, 2015: 48-53). Privatization and deregulation policies contributed to deteriorating working conditions and the rolling back of labor protection and the rights to a state pension, welfare, and national health care saw socioeconomic precarity increase. Unemployment levels increased due to deindustrialization, technological changes and relocation of industries to countries with cheaper labor, and more attractive tax and regulatory environments.

\section{Unstable Democracy and Conjunctural Trigger Factors in the West}

The simultaneous and self-reinforcing narrowing and shallowing of democracy fostered an unstable democratic equilibrium. Shifting balances of power between citizens and elected officials, between state managers and capital, between state managers and supranational agenda-setters, and between labor and capital have witnessed the capture of politics by economic forces, which in turn fosters a thin citizenship regime and rising inequality, which in turn feeds back onto weakened citizen participation in and control over political decision-making. The result of the neoliberal infused de-democratization spiral has been declining trust and participation in traditional democratic channels, and the widening of space for populists to emerge.

While the narrowing and shallowing of democracy help us understand why space for populists widened in Western democracies, analysis of the conjunctural trigger factors helps us comprehend why support for specific types of populist increased relatively quickly in the last decade in particular. The financial crisis of 2007-2009 and the failure of Western politicians to combat the negative effects of the crisis fostered enormous discontent. However, rather than stimulating a reformation of the neoliberal model, the crisis was used to "impose an even more radical neoliberal regime and to push through policies designed to suit the financial sector and the wealthy, at the expense of everyone else" (Mitchell and Fazi, 2017: 1). Long-term austerity measures were (re)imposed in nations, both rich and poor, while "financial and corporate elites got away with slaps on the wrist, if that, only to be compensated in due course with yet more deregulation and further rounds of tax cuts" (Peck and Theodore, 2019: 249). Austerity policies post-2008 led to pauperization and rising levels of precarity for a large part of the middle- and popular-classes fueling a sense of insecurity, inequality levels spiraled upwards, while the lack of any alternative proffered by mainstream political parties delegitimized the party system. In such scenarios, populists thrive.

The rapid rise in support for populists in recent times in Western democracies is also related to rising levels of immigration. While immigration is perceived as a threat by some who resent cultural intermixing and fear an erosion of national values, there is also an economic element that drives resentment toward immigrants. Longer-term neoliberalization processes saw low-skilled decent jobs disappearing in the developed democracies only to be replaced with an increase in temporary contracts in service sectors with low wages (Gidron and Hall, 2017: S64). Such a shift in the quality and quantity of jobs is related to the global expansion in the industrial reserve army of labor due to the collapse of the USSR and the opening of China to foreign capital. Moreover, access to Chinese labor for manufacturing firms witnessed a decline in manufacturing jobs in Mexico, undercutting the NAFTA project. As relatively well-paying jobs disappeared in Mexico, 
Latin American laborers migrated to the US in search of better-paying manufacturing jobs. These longer-term trends intertwined with the post-2008 austerity scenario and, in Europe, the migrant crisis of the 2010s, culminating in rising anti-immigrant sentiment amongst lower-skilled sectors who compete with migrants for increasingly scarce and precarious jobs. In the UK and US, for example, new parties or candidates emerged, indicting traditional politicians for having abandoned "constituents and whole areas of the country and privileging instead the interests of foreign powers, businesses and nationals over their British or American counterparts" (Dunn, 2019: 64). Conjunctural factors including post-2008 austerity and immigration intertwined with longer-term de-democratization processes, generating a scenario in which xenophobic-nationalistic and antiestablishment sentiment flourished.

\section{Types of Populists in Western Democracies}

Those who bore the brunt of austerity while simultaneously witnessing their national governments ignore their pleas for protections were left feeling powerless as their living conditions crumbled around them. Established conservative, liberal, Christian and social democratic parties had for the most part been complicit in the adoption of neoliberal policies. It was therefore "left to new invaders to articulate discontent" (Crouch, 2019: 129). Populists who rejected the political establishment constructed "the people" in "terms of ethno-national and/or religious particularisms more than socioeconomic stratification" (Roberts, 2019a: 197). The refugee and migrant crisis of the 2010s meant that such "ultra-conservative forces found amenable terrain on which to manufacture imaginary threats about hordes of foreigners invading" (Lapavitsas, 2019: 6). Furthermore, the turn away from anti-capitalist class based analyses by mainstream left parties "effectively reduces the left to the role of defender of the status quo, thus allowing the political right to hegemonize the legitimate anti-systemic. . grievances of citizens" (Mitchell and Fazi, 2017: 12). In the vacuum created by the left's adoption of neoliberal policies and post-material concerns, many right-populists shifted their economic stances "leftward," enhancing their appeal to working-class constituencies (Roberts, 2019a: 197). Indeed, Berman and Snegovaya (2019: 10) argue that voters from less privileged socioeconomic backgrounds such as workers with low levels of education have always been conservative on social and cultural issues. However, they also have economic preferences traditionally associated with left-wing parties. As contemporary populists in Western democracies shifted their economic stance in a leftward direction, while social democratic parties drifted to the right in economic terms at the same time as they adopted post-material progressive ideas, voters with conservative social views and left-wing economic demands no longer faced a trade-off; they shifted support away from social democratic parties to the conservative nativist-populists. Such populists have increasingly supported trade protectionism and "welfare chauvinism"- that is, "generous welfare states that concentrate their benefits on 'authentic' members of the ethnonational community, to the partial or complete exclusion of immigrant and minority populations" (Roberts, 2019a: 197).

These populists have advanced most in developed Western democracies with relatively unified labor markets and universalistic welfare states that have come under pressure from the forces of market globalization and immigration (Roberts, 2019a). For example, in France, Jean-Marie Le Pen's National Front originally supported neoliberal, small state policies. However, under the leadership of his daughter, Marine, the National Front now advocates protectionism, an interventionist state, and a strong social safety net for "authentic" French citizens (Berman and Snegovaya, 2019: 9). Similar processes occurred in the Austrian Freedom Party, the Alternative for Germany, UKIP in the UK, and the Sweden Democrats. The central argument here is that the emergence of this breed of populists in the developed democracies, while shaped and amplified by the conjunctural 
trigger factors in the form of the 2008 crisis/austerity and migration crisis, were birthed in longer term neoliberalization processes, which fostered unstable democratic equilibria due to the progressive shallowing and narrowing of democracy. While each case varies, one can identify a general trend in Western democracies. Rollback and rollout neoliberalization processes under right- and center-left parties led to such shallow and narrow democracies that they became unstable. In conditions of rising inequality and socioeconomic precarity, while popular voices were excluded from agenda setting and decision-making processes, apathy and withdrawal were gradually replaced by anger and resentment. The conjunctural causal triggers of economic crisis, austerity, and rising immigration sped up this process, culminating in the emergence of populists who cut across traditional left-right descriptive cleavages. Populists who gained support were those that hearkened back to a pre-globalization era and who promised to deepen and extend democracy by reclaiming national sovereignty - politically and economically — via boosting domestic state managers' capacity to set policy agendas and by calling for protectionist economic stances, which were traditionally more closely associated with leftist politics. Such populists provided a response to understandable demands for greater territorial or national sovereignty in an age of neoliberal globalization, but wrapped these projects in anti-migrant nativist and regressive-reactionary nationalistic terms.

\section{Neoliberalization and the Shallowing and Narrowing of Latin American Democracies}

Following the failure of laissez-faire capitalism during the great crisis of the 1930s, Latin America shifted toward Import Substitution Industrialization (ISI). During this period, corporatism emerged and party-affiliated unions were the politically dominant representatives of popular sectors (Collier and Collier, 1991; Rossi and Silva, 2018: 8). ISI features in urban areas included increased formal sector employment, much of it in the public sector, with labor rights and benefits; and expanded public health, education, housing, and subsidies for basic consumption which protected the popular sector and middle classes from the excesses of the market (Silva, 2009: 21). However, ISI suffered from serious problems. The heavy bias toward urban areas and the fact that the vast majority of labor remained in the informal sector meant that a growing mass of city and rural marginalized poor labored under exploitative conditions (Silva, 2009: 22). Moreover, in countries where a strengthening working class increased pressure for social reform, the "result was not inclusion but dictatorship" (Grugel, 2009: 29). However, these military regimes faced increasing international pressure in the 1980s and transitioned to liberal democracy.

The challenge of building democracies "was complicated by the legacies of erratic economic programs implemented during the years of authoritarian rule and profound economic recession that swept across the region from the late 1970s" (Grugel and Riggirozzi, 2009: 5). ISI policies failed to control the effects of debt crises, and as hyperinflation spiraled, mass street protests erupted. In this scenario, the financial crisis was used as a justification to drive forward an economic liberalization agenda, while the political crisis in the region added to the converging belief amongst business, international aid agencies, financial institutions, and governing elites that the institutions developed under ISI needed to be removed, thus eradicating the social and political roots of the crisis (Grugel and Riggirozzi, 2012). As such, the crisis of ISI and authoritarianism "unleashed the twin processes of free-market economic reforms and democratization that were attempts to construct a contemporary version of market society," whereby economic relations were reorganized on neoclassical principles coupled with the restructuring of "political and social institutions to support free-market capitalism" (Silva, 2009: 23).

While there was variation across countries in the timing, sequencing, and intensity of policies designed to accomplish neoliberal restructuring, all followed a similar pattern (Rossi and Silva, 2018: 
6). First-stage stabilization policies sought to address fiscal, balance of payment, and hyperinflation crises. Balanced budgets, stable unitary exchange rates, restrictive fiscal and monetary policies, high interest rates and limits on public expenditures by firing state employees and cutting ISI-era programs were adopted. Following these initial stabilization policies, structural adjustment reforms were implemented, focusing firstly on liberalization of trade, finance, investment, and agricultural sectors. Deregulation, privatization, and foreign investment were encouraged. Second stage structural adjustment saw social institutions such as healthcare, pensions, education, and social assistance programs realigned along market principles (Rossi and Silva, 2018: 6-7). Finance ministries and central banks were given greater institutional capacity, while other economic line ministers and agencies became subordinate to them (Silva, 2009: 25). Economic, social, and political capital were concentrated in the hands of a reduced number of business groups, local and transnational, who enjoyed privileged access to government in return for providing governments with finance, investment, and legitimacy (Grugel, 2009: 36). Conversely, popular sector access to decision-making channels was limited and unions were decollectivized and depoliticized (Rossi and Silva, 2018: 8). This pattern of isolating executive decisions from popular debate became the modus operandi of Latin American "democracies" as regional governments became increasingly "delegative" (O’Donnell, 1994). Furthermore, financial assistance and policy support from the IFIs was conditional on the adoption of "good" market policies.

In sum, democracy shallowed and narrowed as socioeconomic precarity, flexible labor, and rising inequality became entrenched while decision-making became a distant, elite-led, technocratic process. In such a scenario, there was a common perception amongst popular sectors that democracy had been hijacked by unelected elites and supranational bodies representing the interests of capital and that national sovereignty had been eroded. Capturing this sentiment, a member of a communal council in Caracas, Venezuela, told me "before Chávez, when I was younger and saw someone talking about the constitution we turned off the television because we felt that politics did not matter for us, it was only for 'them'. . . for the rich and their Yankee backers." Such sentiment was common across all interviews I carried out in both Venezuela and Bolivia in 2016-2017. ${ }^{2}$ Neoliberalization processes fostered such a shallow and narrow model of democracy that it came to be understood amongst popular sectors as a tool for the maintenance of domestic-elite privilege and imperialist exploitation.

\section{Unstable Democracy and Conjunctural Trigger Factors in Latin America}

Unsurprisingly, democracy faced a legitimacy crisis with extremely high levels of dissatisfaction with politics and low levels of trust in governments and politicians. Political parties "were perceived as instruments of local and foreign elites that implemented neoliberal policies and thereby increased social inequality" (De la Torre, 2016: 64). As satisfaction with the economically and politically exclusionary market model of democracy sagged, spillovers from the 1997 Asian crisis, falling commodity prices, and IMF-backed austerity triggered waves of mass anti-neoliberal mobilization across the region. Protests represented a struggle for re-incorporation whereby excluded segments of society sought to (re)connect with state institutions so as "to recover - or for the first time gain - access to rights and benefits that the state has failed or ceased to secure or provide" (Rossi, 2015: 3). Movement leaders successfully bound sectorial and group interests together by framing the grievances of women, Afro-Latinos, indigenous groups, urban and rural popular groups, informal workers, and landless peasants amongst others as issues of democratic citizenship that the neoliberal-inspired market-democracy denied. As such, organizations rooted in cultural, identity, and class politics linked together, demanding greater political, social, cultural, and 
economic inclusion and equality, which market democracy had failed to deliver (Silva, 2009: 1). Eruptions of popular discontent were often brutally repressed by state forces, further undermining the legitimacy of the democratic system, unifying protesters, and paving the way for the election of populist leaders (Brown, 2018, 2020).

\section{Types of Populists in Latin American Democracies}

As Roberts (2014) delineates, a progressive-populist response emerged in cases where laborbased and center-left parties were at the forefront of advancing neoliberal policies, a configuration found in Bolivia, Ecuador, and Venezuela. Bait-and-switch adoption of neoliberal policies by center-left parties caused party systems to converge around variants of market orthodoxy, programmatically de-aligning partisan competition and channeling societal opposition into extrasystemic forms of social and electoral protest, thereby opening vacant political space for populist outsiders on the left flank of mainstream parties (Roberts, 2019b). While populist leaders are often portrayed as authoritarian, top-down, imposing figures, such a conception fundamentally misconstrues the nature of the leader-popular base relations in Latin America during antineoliberal mobilization and party system de-composition. For example, in Bolivia, Evo Morales emerged directly from anti-neoliberal movements and sought to adhere to protester demands, at least during his first term as president. Morales had organic links to the coca growers unions as well as the Bartolina Sisa National Confederation of Campesino, Indigenous, and Native Women of Bolivia and the Unitary Syndical Confederation of Peasant Workers of Bolivia (CSUTCB). He also built strategic relationships with urban labor and neighborhood groups who saw in Morales the opportunity to challenge the market-model of democracy at the ballot box. ${ }^{3}$ On the other hand, having witnessed the capacity of organized popular sectors to force pro-neoliberal sitting-presidents Sánchez de Lozada and Carlos Mesa to flee from office, Morales wanted to be sure that he could count on their support. As such, movement leaders were invited to work closely with Morales in setting the agenda during the constituent assembly process. Even in Venezuela, where leader-base relations were closer to a vanguardist model, it was the long-standing grievances of organized sectors of the popular base that shaped Hugo Chávez's emergence and policy proposals. A leading figure in the Venezuelan commune movement and long-time activist summarizes the nature of the relationship between Chávez and the popular base, stating that

Before Chávez, through the history of Venezuela, there have been ebbs and flows of popular movements;
there's a background of guerrillas, of strong social movements. In the $80 \mathrm{~s}$ and $90 \mathrm{~s}$ these organizations
focussed on solving the problems afflicting Venezuelans, such as water supply to the barrios of the big
cities. Like with the anti-neoliberal explosion, the Caracazo in 1989. But there was a difference after the
arrival of Chávez. Before we had explosions of protest and we had demands for an overhaul of the
bourgeoisie democracy. . . but then we would lose the capacity to organize the people as a whole in order
to achieve a change. Until the arrival of President Chávez. He gave us strength. He unified the base and
activated a process of more organized participation and actually unleashed new elements of social
participation. (interview with author)

Reflecting protester sentiment, Chávez, Correa, and Morales engaged in strident critiques of mainstream party systems, promised to extend democracy via redistributions and by restoring protections from market insecurities, and also promised to deepen political participation via plebiscitary measures to convoke constituent assemblies and re-found national democratic regimes (Roberts, 2019b). Latin American populists, then, were accompanied by "popular calls for a different kind of political leadership, demands that ordinary people have more access to the state and better welfare provision and mobilization for policies of cultural recognition and a strengthening 
of communal and indigenous rights (in Bolivia and Ecuador especially)" (Grugel and Riggirozzi, 2012: 7). The emergence of such populists thus (re-)opened a debate regarding the scale and purpose of state intervention in the market, democratic and governance reform, the coverage and content of welfare programs, equality - especially in terms of wealth and income, as well as regional and international policy stances. Rather than seeing individuals as producers and consumers in the market, the Latin American populists proposed to extend democracy by fostering collective rights and solidarities that "aspire to achieve universal social citizenship [representing a] fundamental rethinking of state-society relations, to a greater or lesser extent according to the case" (Beasley-Murray et al., 2010: 4).

The argument here is that the emergence of Latin America's populists was a response to the shallowing and narrowing of democracy over the course of neoliberalization projects. Widespread socioeconomic precarity and exclusion from decision-making channels allowed powerful progressive movements to emerge by framing and binding myriad grievances under an anti-neoliberal democratization banner. These movements and their demands for (re)incorporation then opened space for progressive-populists to capture the space vacated by traditional center-left parties that had shifted to the right. The underdeveloped nature of social citizenship and the dualistic labor market whereby the vast majority of workers are employed in the informal sector sees a divide in society between those with a place in organized, formal society, and those without (Smilde, 2011: 5). As such, and in conjunction with co-opted, exclusionary political decision-making channels, the "other" for progressive-populism in Latin America refers to political and economic elites whose insider status is founded on the exclusion of other sectors of the national community (Roberts, 2019b).

While Latin American populisms sought to reclaim the state from domestic political and economic elites, there was also a transnational element to the projects that challenged imperialism and global capitalism. Latin American populists supported each other politically, ideologically, and economically. Hugo Chávez's access to Venezuela's vast oil reserves played a crucial role in this regard. Regionalist projects such as ALBA were established so as to promote "new geographical and ideological boundaries while fostering new consensuses that are defined regionally, not globally" (Riggirozzi and Tussie, 2012: 6). ALBA rejects the logic of 1990s regionalism that was based on Latin American countries competing to lock-in deregulation and attract foreign investment; rather, ALBA proposed an "alternative model of development and accumulation underpinned by new principles of solidarity and complementarities" (Riggirozzi, 2011: 434). Furthermore, the Bank of the South was established with Venezuelan oil revenues and sought to provide an alternative source of borrowing to the Washington-based IFIs and their associated neoliberal conditionalities.

\section{Democracy, Neoliberalization, Populism: Western and Latin American Cases Compared}

In both the "developed" West and Latin America, democracy became narrower and shallower over the course of neoliberalization processes and in both regions center-left parties shifted to the right in economic terms. However, in Latin America, progressive-populists filled the space opened by party system de-legitimation whereas the West witnessed a surge in conservative nativistpopulism. The simultaneous transition to democracy underpinned by neoliberal rationale in Latin America witnessed a more aggressive rollback of state protections from the excesses of the market than in the West. While labor had been incorporated via corporatist channels during the ISI period in Latin America, it was far weaker in comparison to the West. The majority of the workforce operated in the informal sector and formal sector unions had been battered during the authoritarian 
period, which preceded the transition to liberal democracy. Even in Venezuela where a pacteddemocracy operated from 1958, corporatist labor relations only covered a small portion of the workforce. Meanwhile, structural dependence on IFI borrowing to overcome chronic debt and inflation crises increased the leverage of Washington to impose radical rollback neoliberalization on borrowing states. The impacts of rollback and subsequent rollout neoliberalization on citizens were drastic given the high levels of poverty and the dependence of the majority of citizens on ISIera policies for survival.

The fact that organized labor was weak, that neoliberal policies affected a large swathe of the populace, and that expectations of a transition to a deep-extended model of democracy were dashed allowed a range of popular movements and organizations to frame neoliberalization as a direct challenge to democratic citizenship. Unlike in the West, popular organization leaders bound the grievances of multiple groups and sectors of society together in rejecting the neoliberal project, calling instead for more radical-substantive democratization processe. These protests had been growing in waves over the course of the neoliberalization projects. With the conjunctural trigger factors of the late 1990s commodity price crash, spillover from the Asian crisis as well as growing state-repression of protests, the region witnessed an explosion of mass anti-neoliberal protest that forced presidents who adopted IMF-imposed austerity policies to flee from office. In the Andean cases, it was the organized popular sectors who opened spaces for progressive-populists to emerge on promises not only to extend democracy, but to open new avenues for popular access to decision-making channels. Conversely, in the Western cases, longer-term neoliberal processes and conjunctural-trigger factors did not foster the growth of such powerful, progressive protest movements, and the populists that emerged did not have organic connections to the popular base.

Unlike Western cases, Latin America's populists did not scapegoat immigrants. The general lack of a developed welfare state, exclusion from formal-sector labor markets, higher levels of poverty and inequality, and lower levels of immigration meant that popular demands and populists focused less on defending the economic pie from outsiders and more on achieving materialistic benefits for popular sectors in the first place. Hence, while Latin American populism was premised on gaining inclusion - political and socioeconomic — into the national community for long-excluded popular sectors, Western populism was instead premised on efforts to separate those who authentically "belong" and are "worthy" of inclusion from "different others" who are deemed to be legitimately excludable (Roberts, 2019b). Latin American popular organizations, instead of calling on the state to protect welfare systems or job quality from "undeserving nonnationals," demanded state protections from capital. Moreover, given Latin America's position as a post-colonial developing region and the sentiment that the US and the IMF in particular were seeking to curb both national and regional sovereignty, popular sectors and populists adopted a progressive-internationalist stance that not only sought to curb the influence of unelected external (f)actors such as foreign capital and IFIs, but also advocated international solidarity with regional socialist/progressive parties and leaders. Hence, while Latin American populists shared some characteristics with Western cases regarding the need to re-claim national sovereignty, Latin American populists supported regionalist integration projects founded on socialist principles and rejected the exclusionary nativism and regressive-reactionary nationalism prevalent in the West.

\section{Conclusion}

Variegated neoliberalization processes fostered varied forms of de-democratization in the West and Latin America. While space for populists widened in both cases as a result of the narrowing and 
shallowing of democracy, differing constellations of austerity, immigration and movement power shaped the populist responses to crises of too little democracy. In Latin America, there were calls for a re-claiming of the state from political and economic elites so as to allow for a democratization process that entailed a simultaneous deepening and extending of political and socioeconomic citizenship for popular sectors. In comparison to Western populists, calls for such democratization offered a radical challenge to the market model of democracy - that is, thin liberal democracy underpinned by neoliberal rationale. With progressive movements in the West unable to frame the genuine grievances of vulnerable sectors around a radical-substantive democratization project that critiques global capitalism, conservative nativist-populists seized the moment by appealing to nostalgic nationalist notions of supposedly former glory days. Populism in the West looks to an imagined past; Latin American populism looks to an imagined future. This is not in any way to diminish the tremendous issues that Latin American populists have fostered following election such as centralization of power in the executive, quashing of legitimate opposition, and co-opting of progressive but contentious popular movements (see Brown, 2018, 2020). However, popular-sector movement-organizing and issue-framing regarding a deepening and extending re-democratization project, while supporting progressive-internationalism highlight what the target for progressive forces in the West should be if they wish to challenge the surging support for conservative nativistpopulists. While conjunctural triggers of austerity and immigration undoubtedly shaped the populist turn in the West, it is important to remember that such factors had such resonance due to longer-term neoliberalization processes. Challenging conservative nativism therefore requires progressive forces - at grassroots and party levels - to propose alternatives to neoliberal-style citizenship where socioeconomic security is guaranteed, and, crucially, where citizens rather than investors and distant technocrats are seen to shape agendas and decision-making processes. Analysts who conflate Western and Latin American experiences and who berate populists for threatening the norms and survival of democracy fail to grasp that it is precisely the functioning of neoliberal-infused democracy that brings about its own challengers. Furthermore, if the agenda has been set to benefit capital before citizens participate in the democratic process, why would those long-excluded sectors care about protecting the guardrails of democracy once a populist leader is elected to power? Democracy in its market incarnation is understood by popular sectors as a veil to maintain privilege, a tyranny of an elite minority. Even if the current "populist moment" passes, until the market model of democracy is jettisoned, democracy will remain in unstable equilibrium, awaiting the next crisis of capitalism which will once more open space for populist challengers to emerge, just as Karl Polanyi noted 75 years ago.

\section{Funding}

This research received no specific grant from any funding agency in the public, commercial, or not-for-profit sectors.

\section{ORCID iD}

John Brown (iD https://orcid.org/0000-0002-6224-8015

\section{Notes}

1. For the remainder of the article, the terms "West," "Western," and so forth relate to North Western Europe and the United States.

2. In Venezuela, interviewees included members of communal councils from the popular zones of El 23 de Enero and Petare in Caracas who had participated in anti-neoliberal protests in the 1980s and 1990s. In Bolivia, interviews were carried out in the indigenous, popular city of El Alto. Interviewees included members of neighborhood councils and trade unions as well as leaders of the anti-neoliberal protests that engulfed the city during the 2003-2005 period. 
3. Information gathered during fieldwork and based on interviews with five protest leaders from the 20032005 period in El Alto.

\section{References}

Ayers AJ and Saad-Filho A (2015) Democracy against neoliberalism: paradoxes, limitations, transcendence. Critical Sociology 41(4-5): 597-618.

Bartels LM (2018) Unequal Democracy: The Political Economy of the New Gilded Age. New Jersey, NJ: Princeton University Press.

Beasley-Murray J, Cameron MA and Hershberg E (2010) Latin America's Left Turns: Politics, Policies, and Trajectories of Change. Boulder, CO: Lynne Rienner.

Berman S and Snegovaya M (2019) Populism and the decline of social democracy. Journal of Democracy 30(3): 5-19.

Blofield M (2011) The Great Gap: Inequality and the Politics of Redistribution in Latin America. Pennsylvania, PA: Penn State Press.

Brenner N, Peck J and Theodore N (2014) New constitutionalism and variegated neo-liberalization. In: Gill S and Cutler AC (eds) New Constitutionalism and World Order. New York, NY: Cambridge, 126-142.

Brown J (2018) Escaping the confines of market democracy: lessons from Venezuela. Socialism and Democracy 32(2): 14-31.

Brown J (2020) Party-base linkages and contestatory mobilization in Bolivia's El Alto: subduing the Ciudad Rebelde. Latin American Perspectives 47(4).

Collier RB and Collier D (1991) Shaping the Political Arena: Critical Junctures, the Labor movement, and Regime Dynamics in Latin America. New Jersey, NJ: Princeton University Press.

Crouch C (2019) Post-democracy and populism. The Political Quarterly 90(S1): 124-137.

De la Torre C (2016) Left-wing populism: inclusion and authoritarianism in Venezuela, Bolivia, and Ecuador. Brown Journal of World Affairs 23(1): 61-76.

Dunn J (2019) The challenge of populism: why populist politics spreads in the world. Populism 2(1): 53-67.

Gidron N and Hall P (2017) The politics of social status: economic and cultural roots of the populist right. The British Journal of Sociology 68(S1): S57-S84.

Gill S (1998) New constitutionalism, democratisation and global political economy. Global Change, Peace and Security 10(1): 23-38.

Grugel J (2009) Basta de realidades, queremos promesas. In: Grugel J and Riggirozzi P (eds) Governance After Neoliberalism in Latin America. New York, NY: Palgrave Macmillan, 22-48.

Grugel J and Riggirozzi P (2009) The end of the embrace? Neoliberalism and alternatives to neoliberalism in Latin America. In: Grugel J and Riggirozzi P (eds) Governance After Neoliberalism in Latin America. New York, NY: Palgrave Macmillan, 1-23.

Grugel J and Riggirozzi P (2012) Post-neoliberalism in Latin America: rebuilding and reclaiming the state after crisis. Development and Change 43(1): 1-21.

Lapavitsas C (2019) The Left Case Against the EU. London: Polity.

Mair P (2013) Ruling the Void: The Hollowing of Western Democracy. New York, NY: Verso.

Mitchell W and Fazi T (2017) Reclaiming the State. Chicago, IL: University of Chicago Press Economics Books.

O’Donnell G (1994) Delegative Democracy. Journal of Democracy 5(1): 55-69.

Peck J and Theodore N (2019) Still neoliberalism? The South Atlantic Quarterly 118(2): 245-265.

Peck J, Brenner N and Theodore N (2018) Actually existing neoliberalism. In: Cahill D, Cooper M, Konings $\mathrm{M}$, et al. (eds) The SAGE Handbook of Neoliberalism. London: Sage, 3-15.

Piketty T (2015) About capital in the twenty-first century. American Economic Review 105(5): 48-53.

Riggirozzi P (2011) Region, regionness and regionalism in Latin America: towards a new synthesis. New Political Economy 17(4): 421-443.

Riggirozzi P and Tussie D (2012) The rise of post-hegemonic regionalism in Latin America. In: Riggirozzi P and Tussie D (eds) The Rise of Post-Hegemonic Regionalism. Dordrecht: Springer, 1-16.

Roberts K (1998) Deepening Democracy? The Modern Left and Social Movements in Chile and Peru. California, CA: Stanford University Press. 
Roberts K (2014) Changing Course: Party Systems in Latin America's Neoliberal Era. New York, NY: Cambridge University Press.

Roberts K (2019a) Crises of representation and populist challenges to liberal democracy. Chinese Political Science Review 4(2): 188-199.

Roberts K (2019b) Bipolar disorders: varieties of capitalism and populist outflanking on the left and right. Polity 51(4): 641-653.

Robinson W (2012) Global capitalism theory and the emergence of transnational elites. Critical Sociology 38(3): 349-363.

Rossi FM (2015) The second wave of incorporation in Latin America: a conceptualization of the quest for inclusion applied to Argentina. Latin American Politics and Society 57(1):1-28.

Rossi FM and Silva E (2018) Introduction: reshaping the political arena. In: Silva E and Rossi FM (eds) Reshaping the Political Arena in Latin America: From Resisting Neoliberalism to the Second Incorporation. Pennsylvania, PA: University of Pittsburgh Press, 3-20.

Schattschneider EE (1960) The Semi-sovereign People: A Realist's View of Democracy in America. Hinsdale III: Dryden.

Schmitter PC (2019) "Real-existing" democracy and its discontents: sources, conditions, causes, symptoms, and prospects. Chinese Political Science Review 4(2): 149-163.

Silva E (2009) Challenging Neoliberalism in Latin America. New York, NY: Cambridge University Press.

Smilde D (2011) Introduction: participation, politics and culture - emerging fragments of Venezuela's Bolivarian Democracy. In: Smilde D and Hellinger D (eds) Venezuela's Bolivarian Democracy: Participation, Politics, and Culture under Chávez. Durham and London: Duke University Press, 1-27.

Solt F (2008) Economic inequality and democratic political engagement. American Journal of Political Science 52(1): 48-60. 